Enrique Rodriguez, Rocha is president of the Mexico City office of $H V S$ International, the world's foremost consulting company catering exclusively to the hospitality industry. He possesses over 15 years of experience in the Mexican tourism and real estate business, co-founding HVS Mexico City after handling over US\$90m in Mexican hotel and tourism transactions.

Greg Zorella

is director of development new businesses for HVS International. Greg is also president of

hospitalitycareernet.com, HVS International's Internet-based staffing solution for hospitality industry employers and job seekers.

Keywords:

Mexico, lodging, investment, sales

Gregory L. Zorella

President, hospitalitycareernet.com 372 Willis Avenue,

Mineola, NY 11501, USA

Tel: 5162488828

Fax: +1 5167421905

E-mail:

gzorella@hospitalitycareernet.com

\section{The Mexican lodging market}

\author{
Enrique Rodriguez Rocha and Greg Zorella \\ Received (in revised form): 26th July, 2000
}

\begin{abstract}
The recovery of the Mexican economy from the doldrums of the mid1990s' financial crisis has created an ideal environment for foreign lodging investors looking to get their feet wet. Government entities are disposing of lodging real estate and debt they absorbed during a bailout of the Mexican banks in 1995, creating attractive buying opportunities. At the same time, sustained economic improvement has enhanced Mexico's stature as a viable long-term investment target.
\end{abstract}

\section{INTRODUCTION}

Year in and year out, the number of hotel transactions occurring in Mexico is a fraction of what it is in the USA, a country its economy depends heavily upon. This is a function of several factors, the most important of which is that Mexico's lodging market is substantially smaller than that of the USA. That should be expected from a country of roughly 99 million people when compared with a nation of almost 260 million people. Mexico DF (Mexico City), the capital of Mexico, boasts a population more than double the size of New York City. Yet, in 1999, Mexico City's average daily room count totalled only 47,000 guestrooms, as compared to roughly 57,500 guestrooms for New York City.

Nationwide guestroom supply in Mexico has also historically lagged behind that of the USA, for obvious reasons. However, Mexico has improved its stature in recent history, as supply growth has exceeded that of the USA in four of the last five years. In fact, guestroom supply in Mexico, which recorded 2.6 per cent average annual growth from 1990 through to 1999, outpaced that of the USA over the course of the decade by more than 0.5 per cent (Table 1).

Aside from critical mass issues, the low number of hotel transactions in the past is also a reflection of the difficulty of finding both legally saleable hotel properties and hotel owners willing to sell at market-level prices. The sale prices listed by Mexican hotel owners have rarely had anything to do with the hotels' business value. Rather, it is usually a case of owners paying too much to build excessively opulent properties and expecting to get a sales price equal to the construction cost.

Purchasing hotel debt is another option that has typically been ruled out, due to the legal difficulties and uncertainties surrounding foreclosure procedures in Mexico. The bottom line is that the Mexican lodging market is not an efficient one. Attempting to 


\section{Guestroom supply in Mexico actually grew faster than that in the USA from 1990 to 1999.}

Table I: Guestroom supply (1990-1999)

\begin{tabular}{lcccc}
\hline & \multicolumn{2}{c}{ Mexico } & \multicolumn{2}{c}{ USA } \\
\cline { 2 - 5 } Year & $\begin{array}{c}\text { Guestroom } \\
\text { supply }\end{array}$ & $\begin{array}{c}\% \\
\text { change }\end{array}$ & $\begin{array}{c}\text { Guestroom } \\
\text { supply }\end{array}$ & $\begin{array}{c}\% \\
\text { change }\end{array}$ \\
\hline 1990 & 333,547 & - & $3,176,000$ & - \\
1991 & 345,159 & 3.5 & $3,221,000$ & 1.4 \\
1992 & 355,189 & 2.9 & $3,245,000$ & 0.7 \\
1993 & 366,423 & 3.2 & $3,255,000$ & 0.3 \\
1994 & 363,579 & $(0.8)$ & $3,290,000$ & 1.1 \\
1995 & 370,298 & 1.8 & $3,332,000$ & 1.3 \\
1996 & 381,522 & 3.0 & $3,409,000$ & 2.3 \\
1997 & 382,364 & 0.2 & $3,527,000$ & 3.5 \\
1998 & 396,968 & 3.8 & $3,667,000$ & 4.0 \\
1999 & 419,608 & 5.7 & $3,795,000$ & 3.5 \\
& & & & \\
Average annual & & 2.6 & & 2.0 \\
change (1990-1999) & & & & \\
\hline
\end{tabular}

Source: Secretaria de Turismo, Mexico; Smith Travel Research; HVS International

predict future trends is usually a frivolous task, since the information upon which you are basing your assumptions shows little in the way of historical trends. The important thing to remember is that inefficiency swings both ways, and it now appears to be favouring the savvy lodging investor.

\section{TRANSACTION DATA}

HVS International has researched historical hotel transactions in the Mexican lodging market since 1995. The results of this research are presented in Table 2 .

One should note two transactions not included in Table 2 that took place in 1997 and 2000 involving the Quinta Real hotel chain. Most recently, the Martínez family reacquired a 66 per cent interest in Quinta Real's management division (on top of the 33 per cent it already owned), and a 100 per cent interest in Quinta Real's real estate division; the family had relinquished its ownership in both divisions to Grupo Chartwell (a conglomerate comprising Goldman Sachs, Grupo Piasa and the Elias family) in the \$20m 1997 transaction. The total amount paid to Grupo Chartwell by the Martínez family in its year 2000 reacquisition was reported to be $\$ 34.5 \mathrm{~m}$. It is important to note that Quinta Real's real estate division owns only partial interests in six lodging properties. Because no allocation between the management company and the real estate company was made available. The sales listed in Table 2 take into account the full value of this transaction

Such is also the case with the \$212 million sale of Camino Real package \#1. In March, 2000 Grupo Empresarial Angeles purchased the 2,287-room package from IPAB, which included both the real estate and the Camino Real management company. Since no allocation was made available, the total transaction price (minus the portion attributable to the Camino Real property in Texas, USA) is made available in Table 2. 
From 1995 to 1998 , the number of annual hotel transactions in Mexico grew
$80 \%$ to $90 \%$ of Mexico's ladging transactions involved foreign investors
Table 2: Hotel transactions in Mexico

\begin{tabular}{lccccrr}
\hline Year & $\begin{array}{c}\text { No of } \\
\text { transactions }\end{array}$ & $\begin{array}{c}\text { Total } \\
\text { value }\end{array}$ & $\begin{array}{c}\% \\
\text { change }\end{array}$ & $\begin{array}{c}\text { No of } \\
\text { rooms }\end{array}$ & $\begin{array}{c}\text { Average price } \\
\text { per room }\end{array}$ & $\begin{array}{c}\% \\
\text { change }\end{array}$ \\
\hline 1995 & 1 & $\$ 32,530,000$ & - & 471 & $\$ 69,066$ & - \\
1996 & 4 & $\$ 186,000,000$ & 472 & 1,592 & $\$ 116,834$ & 69 \\
1997 & 5 & $\$ 176,000,000$ & -5 & 1,261 & $\$ 139,572$ & 19 \\
1998 & 14 & $\$ 465,652,690$ & 165 & 3,691 & $\$ 133,031$ & -10 \\
1999 & 5 & $\$ 100,900,000$ & -78 & 1,474 & $\$ 68,453$ & -46 \\
$2000 *$ & 24 & $\$ 463,012,329$ & 359 & 5,539 & $\$ 91,766$ & 22 \\
& & & & & & \\
Totals & 53 & $\$ 1,424,095,019$ & & 14,028 & $\$ 101,518$ & \\
\hline
\end{tabular}

*Includes sales under contract through second quarter

Source: Lodging DataBank (HVS International)

It is also important to point out the sale of the Dominican Republic's Allegro Resorts to Spain's Occidental Hoteles in April 2000 for $\$ 437 \mathrm{~m}$. This 23 -hotel transaction included six Allegroowned properties in Mexico that are in excellent condition, although an allocation as to the value of these properties is difficult since the transaction included both real estate and management contracts. The sales price for the Mexican resorts is an estimate based on a per-room allocation of the total transaction price.

\section{Transactions: $1995-1999$}

The transaction data are a prime example of how Mexico's lodging market defies any particular pattern or trend. This relates to the critical mass issue presented earlier; how can a dataset with so few pieces of information indicate an industry trend?

What the data can provide is a definition of the current situation in the Mexican lodging industry for newcomers. The number of hotel transactions in Mexico grew from a single transaction in 1995 to as many as 14 (including the Quinta Real transaction) in 1998, as the nation recovered from a deep economic recession brought on by political turmoil in late 1994. It is important to point out this recovery coincided with a surge in the US financial markets during the mid- to late 1990s. Acquisition activity in the US lodging market during this period had a pronounced effect on acquisition activity in the Mexican market, as US entities were responsible for at least $\$ 450 \mathrm{~m}$ in acquisitions from 1996 through to 1999 (roughly 50 per cent of the total sales volume over this period).

Furthermore, research conducted by HVS International suggests that hotel transactions in Mexico during this period typically featured the involvement of foreign investors; depending on how one interprets the numbers, only \pm 10 per cent to \pm 20 per cent of the time does a lodging transaction in Mexico not involve an investor from outside Mexico (Table 3).

The total value of lodging transactions in Mexico showed mixed growth between 1995 and 1999, with an explosion in sales volume occurring in 1996, when $\$ 186 \mathrm{~m}$ in hotel deals were closed, versus only $\$ 32,530,000$ in sales in 1995 . Most of the 1996 volume is attributable to Host Marriott and Marriott International's purchase 


\section{In 1998, Grupo Chartwell accounted for roughly $38 \%$ of the total transaction volume in Mexico}

\section{The IPAB bank fund was formed following the country's mid- 1990's economic crisis}

Table 3: Foreign involvement in Mexican lodging transactions

\begin{tabular}{lcc}
\hline Origin & $\begin{array}{c}\text { \% of transactions } \\
\text { by number of units }\end{array}$ & $\begin{array}{c}\text { \% of transactions } \\
\text { by sales volume }\end{array}$ \\
\hline Foreign & 73 & 64 \\
Joint venture & 19 & 17 \\
Domestic & 8 & 19 \\
\hline
\end{tabular}

Source: Lodging DataBank (HVS International)

of a 90 per cent interest in the Continental Plaza and JW Marriott hotels in Mexico City from Grupo Situr for an estimated \$160m.

Sales volume dipped slightly in 1997 before posting a gain of 165 per cent from 1997 to 1998. In 1998, the then Canadian Pacific acquired the Princess Hotels package that included two properties in Acapulco totalling 1,363 rooms. Going by the per-room package price of $\$ 178,630$, the combined sale price of these properties is estimated to be roughly $\$ 243 \mathrm{~m}$ although it should be mentioned that the value of the Acapulco property is probably much less.

Also in 1998, Grupo Chartwell spent an estimated $\$ 170 \mathrm{~m}$ to $\$ 180 \mathrm{~m}$ in its acquisition of the six aforementioned Quinta Real Hotels, four Krystal Hotels, and a Hilton Hotel in Guadalajara. Total sales volume in Mexico dipped by roughly 78 per cent in 1999 over 1998, as the number of total transactions declined by nine, and several depreciated properties brought the total sales volume and average price per room down.

The primary reason for the drop-off in sales volume between 1998 and 1999 was the postponement of the sale of Camino Real Hotels and Resorts by the Mexican government's IPAB bank fund (formerly known as FOBAPROA). IPAB was created in the wake of Mexico's mid-1990s' peso debacle to absorb nearly $\$ 70$ bn in both Mexican bank loans that had gone into default and realestate-owned properties (REOs). The Camino Real portfolio of luxury hotels, vacant land, condominiums and an office building was absorbed by IPAB during the mid-1990s and subsequently put up for sale in April 1998, with the anticipation of closing sometime in 1999. However, IPAB was not satisfied with any of the bids, and did not resume the sale process until early 2000 .

\section{HOT AND COLD MARKETS}

Roughly 90 per cent of Mexico's hotel sales since 1995 occurred in the Mexico City, Puerto Vallarta, Cabo, Cancun and Acapulco/ Ixtapa markets. Figure 1 shows the distribution in sales volume between Mexico's major hotel markets from 1995 through to 1999. Note that the sales price of the two Princess Hotels in Acapulco has been adjusted to reflect a value more in line with market trends.

As expected, the Mexico City market accounts for a plurality of sales volume nationwide; roughly 41 per cent of all money spent in acquisitions in Mexico from 1995 through to 1999 was spent on properties in Mexico City. The remaining 59 per cent was spent in 
Mexico City accounted for $41 \%$ of the total lodging sales in Mexico from 1995 to 1999

The Gabo area of Mexico's Baja California Sur is the most attractive market for investors at the moment

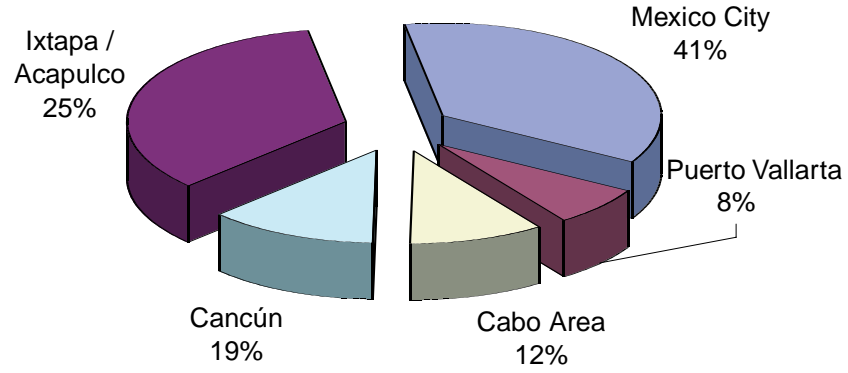

Figure 1: Hotel sales volume in Mexico's major markets (1995-1999)

the resort areas of Cabo, Cancun, Puerto Vallarta and Ixtapa/ Acapulco. It should be noted that sales in markets other than these five, such as Monterrey and Huatulco, accounted for roughly 10 per cent of the total sales volume in Mexico from 1995 through to 1999.

For comparison purposes, the distribution of lodging supply in Mexico by market was examined; the results are presented in Figure 2. One should note that the chart only takes into account supply in the five key markets mentioned previously. These markets represent the bulk of the quality lodging supply in Mexico, while the majority of properties outside of these key markets tend to be unreliable in quality.

A comparison between Figures 1 and 2 gives an indication of the more popular markets in Mexico at the moment, as well as which markets investors are shying away from. Clearly, Cabo has been Mexico's hottest lodging market over the past five years; while it makes up only 5 per cent of the total guestroom supply for Mexico's major markets, 12 per cent of the total sales volume in Mexico from 1995 through to 1999 took place there.

Acapulco has also been a hot market for acquisition activity, mainly because overbuilding and undermaintained properties have brought values down. Once Mexico's marquee resort area, Acapulco has been surpassed in prestige over the last decade by newer resort markets such as Cabo and Cancun. This has fuelled savvy investors seeking profitability by buying low.

On the flip side, Cancun has been less attractive to investors looking to acquire hotels in recent history. Although it possesses

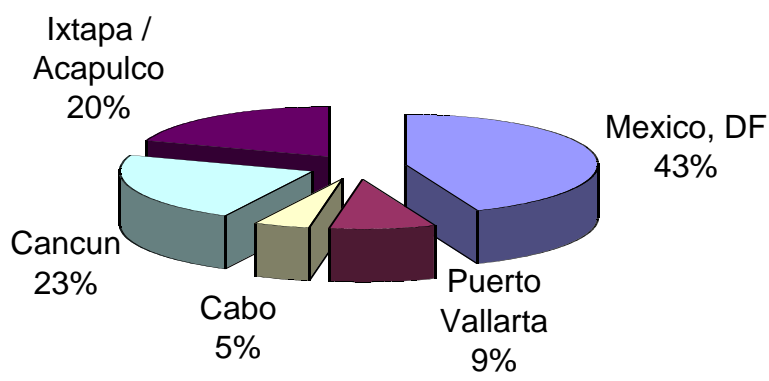

Figure 2: Total guestroom supply by market (1999) 


\section{Mexico City and Puerto Vallarta are the most stable of Mexico's major lodging markets}

roughly 23 per cent of the guestroom supply of Mexico's major markets, Cancun accounted for only 14 per cent of the sales volume in Mexico from 1995 through to 1999. Investors in the Cancun area have found the development of new resorts in areas such as Playa del Carmen to be a more attractive investment than acquiring existing resorts. As the availability of affordable beachfront land in these areas diminishes, interest in acquiring existing lodging facilities should pick up.

It is interesting to point out that Mexico City, which accounts for 41 per cent of the guestroom supply in Mexico's major markets, recorded 36 per cent of the total sales volume in Mexico from 1995 through to 1999, the closest proportion between guestroom supply and total sales volume of any of the five major markets. This would suggest that Mexico City is the country's most stable market at the moment, with Puerto Vallarta a close second.

\section{LOOKING AHEAD}

Savvy investors should open their minds to the fact that there are some significant financial opportunities to investing in lodging real estate in Mexico. Expense ratios, for example, usually hover around 65 per cent of total revenue for a typical full-service hotel in Mexico, as compared to around 75 per cent of total revenue for a similar hotel in the USA or Europe. This is a substantial saving that is predominantly a function of the fractional costs of labour in Mexico versus the USA and Europe.

International investors can also benefit from exchange rate factors. As Figure 3 shows, the Mexican peso is a currency that has historically depreciated versus the dollar.

Revenues collected by most Mexican lodging facilities are denominated in US dollars, and most expenses are paid out in Mexican pesos, which is advantageous to international investors in two ways. Firstly, investors benefit from the expense reduction brought on by the depreciation of the peso in the lag time between revenue collection and expense disbursement. Secondly, since what is left over after expenses is all dollar denominated, investors can remove their money from Mexico while sidestepping exchange rate risks.

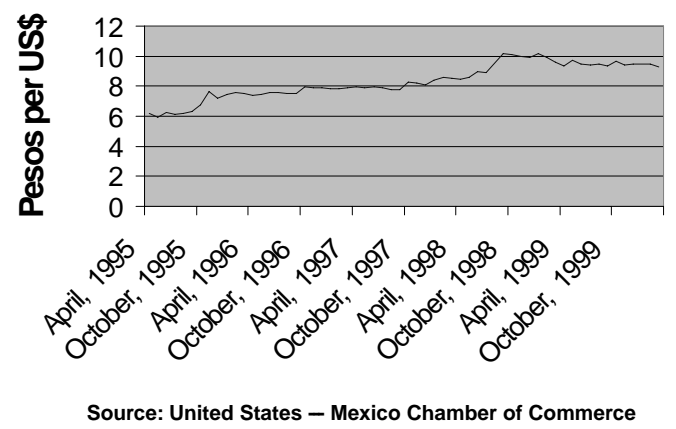

Figure 3: Average monthly exchange rates - Mexican pesos per US\$ 


\section{Foreign lodging investors in Mexico can benefit from the depreciation of the Mexican Peso and decreased exchange rate risks}

\section{Change in government has led to a level of investor confidence in Mexico not seen in some time}

The future growth of hotel transactions in the Mexican lodging market will depend largely on the open-mindedness of foreign investors looking to spend money in Mexico, as well as on the country's macroeconomic situation, which appears quite promising at the moment but, as mentioned previously, can sometimes be unpredictable. Referring back to Figure 3, the peso has been deceptively quiet as of late, while Mexico's gross national product (GNP), shown in Figure 4, has experienced healthy growth since plummeting by 6.2 per cent in 1995 . The country's consumer price index, which skyrocketed to 52 per cent in 1995, has also returned to pre-crisis levels, and at 12.3 per cent for 1999 was at its lowest level since before the economy's collapse.

A tribute to the maturity of Mexico's economy came in the form of the country's recent presidential election. While many predicted that a win by the upstart PAN party would trigger a wave of social unrest, it has been nothing but smooth sailing since the 2nd July victory by PAN's Vicente Fox. Investor confidence has picked up where it left off before the election, and the country is well on the way to eliminating the negative implications of common party, government and state interests.

While the new government has been met with open arms abroad and little resistance at home, Mexico still faces a few challenges on the road to relative economic stability. A rebellion in the southern province of Chiapas, the ever-increasing income disparity between the lower and upper class, the lingering effects over the government's bailout of the Mexican banks (which, ironically, is the impetus for a continued run of lodging sales that is forecast for 2000 and 2001) and corruption, among others, are all conditions that will continue to challenge the country's economic outlook regardless of who is at the helm.

Furthermore, investors new to Mexico will probably find doing business throughout the country a challenge. It generally takes one or two years to truly become acclimatised to the Mexican business environment and able to make informed investment decisions. Companies such as Starwood, Sol Meliá and Marriott accepted these challenges early on and have been doing business successfully

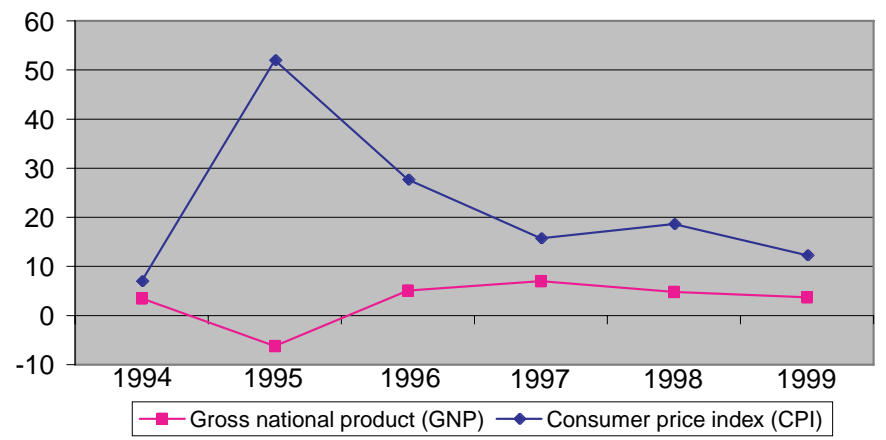

Figure 4: Mexico's GNP and consumer prices 
The Camino Real portfolio is the largest lodging transaction to have taken place in Mexico this year, valued at \$212m
The Grupo Situr portfolio looks to be the largest lodging package to be placed on the Mexican market in 2000 in Mexico for a while. Now is an opportune time for new investors to accept the risks and join these pioneers. Their acclimatisation process can be facilitated by enlisting the services of local experts who 'speak the language', both literally and figuratively.

\section{TRANSACTIONS: 2000 AND BEYOND}

For those cognisant of the challenges and willing to assume the risks, 2000 has already been a year of opportunity for lodging investors in Mexico. In fact, 2000 (spilling over into 2001 and possibly 2002) is shaping up to be a hot year for acquisition activity in the Mexican lodging market, with the biggest sellers continuing to be government-related entities disposing of assets acquired during the mid-1990s' economic crisis at or below replacement cost. We have already witnessed the sale of the Camino Real portfolio by IPAB (as well as three individual Camino Real properties), and several other hotel packages, as well as a number of individual hotel assets, are expected to be bought up during the current wave of acquisition activity. The following is a glimpse of hotels throughout Mexico that it anticipated will be placed on the market in the remainder of 2000.

\section{Camino Real portfolio}

The Camino Real portfolio is being sold in a combination of packages and individual assets. The main package was already sold this year for roughly $\$ 212 \mathrm{~m}$; although the transaction price was listed by a number of sources as $\$ 252 \mathrm{~m}$, there were actually $\$ 40 \mathrm{~m}$ in cash reserves that were acquired in addition to the real estate. The purchaser of this portfolio, the Grupo Empressarial Angeles, acquired the rights to the Camino Real brand name, management contracts owned by the company, and luxury hotel properties totalling 2,287 rooms in Mexico City, Cancun, Puerto Vallarta, Guadalajara, Acapulco, Saltillo (minority interest) and El Paso, Texas.

The Camino Real package also included the office buildings that house the Camino Real headquarters, vacant land, and other independent lodging properties owned by the company. A 234room hotel, marina and golf course in Las Hadas, Manzanillo, which was originally part of this portfolio, was under contract for individual sale at the time of writing for an additional $\$ 15 \mathrm{~m}$.

The Mexican government is also selling off several individual assets of the Camino Real portfolio. Three hotels totalling 572 guestrooms have already been sold for a combined $\$ 22 \mathrm{~m}$, while vacant land in Cancun, Cozumel and Manzanillo, as well as condominiums in Manzanillo, are currently still on the market.

\section{Grupo Situr portfolio}

Grupo Situr has placed a hotel portfolio on the market consisting of nine hotels to be sold collectively, and another ten properties which will be sold individually. The 2,407-unit package includes 
2000 has already become a recordbreaking year in terms of lodging sales volume in Mexico

\section{It has historically been more feasible to build hotels in Mexico than to buy existing hotels due to supply constraints}

Continental Plaza Hotels in Cancun, Playacar and Veracruz; Hoteles Sierra hotels in Nuevo Vallarta and Cancun; Plaza Las Glorias hotels in Cabo San Lucas, Puerto Peñasco and Cozumel; and one Hacienda Bajamar hotel in Baja California. It was understood at the time of writing this article that the sale of this package to a joint venture between US-based Apple Vacations and a Mexican partner was nearing fruition. The transaction price is expected to be in the area of US\$260 million.

Individual properties that will be put up for sale as part of the Grupo Situr portfolio include Continental Plaza hotels in Puerto Vallarta, Acapulco, Mexico City and Ixtapa; one Hoteles Sierra in Manzanillo; one Plaza Las Glorias in Puerto Vallarta; a Pelicanos in Puerto Vallarta; and El Mirador hotels in Acapulco and Cancun. In total, the individual sale properties from the Grupo Situr portfolio encompass 2,038 guestrooms. Additionally, a package of golf courses in locations such as Ixtapa and Playa del Carmen will also be disposed of in the short term as part of the Grupo Situr portfolio.

\section{Other hotels for sale}

In addition to these two large portfolios, 21 other hotels either have been or will be placed on the market in 2000. Already on the market are the 1,350-room Hoteles Aristos chain (six hotels) and the 1,780-room Hoteles Blue Bay chain (five hotels). The remaining ten properties, which will be put on the market later this year by Mexican banks, the Mexican government and the FONATUR agency, total 1,666 guestrooms and are located in areas such as Acapulco, San Jose del Cabo, Manzanillo and Tijuana.

Both 2000 and 2001 have all the makings of being recordbreaking years in terms of hotel sales volume in Mexico. More than 35 hotels are expected to be sold off over the next two years, versus just 23 from 1995 through to 1999 combined. In fact, after less than seven months, 2000 had already become a record-breaking year in terms of total sales volume, with over $\$ 463 \mathrm{~m}$ in transactions having taken place.

\section{THE BUILD-VERSUS-BUY DILEMMA}

The current wave of dispositions represent buying opportunities never before seen in Mexico. Hotel properties are in short supply throughout the country, which is why it has historically been cheaper to build hotels and resorts in Mexico than to acquire them. In fact, the only time in recent history that annual room-night demand growth exceeded annual guestroom supply growth was in the wake of the economic collapse of the mid-1990s, after which any sort of lodging investment was extremely speculative, and all kinds of real estate development came to a halt.

As Figure 5 shows, demand growth had just about caught up with supply growth by the end of 1999, indicating that replacement cost is rising and acquisition may be more cost-effective. The fact 


\section{Annual room night demand growth in Mexico hotels exceeded that of the USA in four of the last five years}

\section{Tourism accounts for an estimated $40 \%$ of Mexico's annual room night demand}

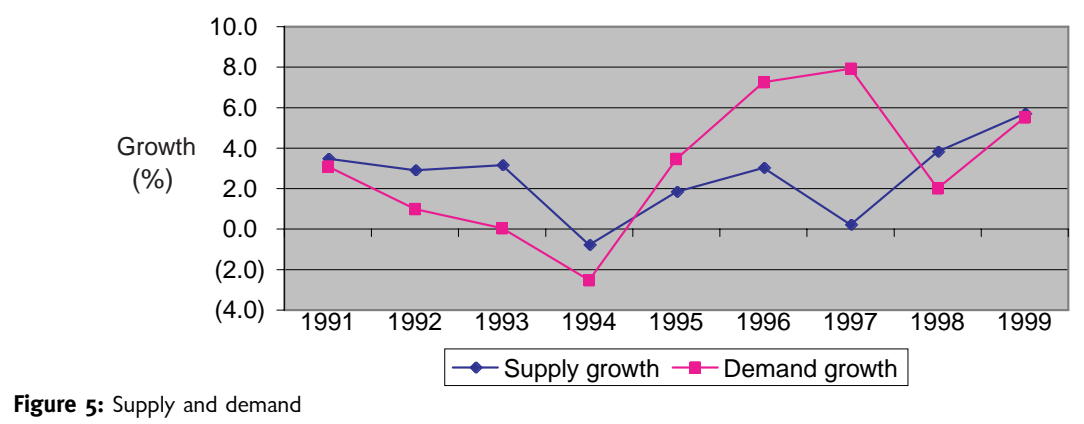

that there are dozens of hotels being liquidated at or below replacement cost by government entities and banks would seem to support this prognosis.

Strong demand growth in recent years is yet another reason for investors to take a more serious look at lodging investment in Mexico. As with supply growth, annual room-night demand growth in Mexico has exceeded that of the USA in four of the last five years, with the only anomaly occurring in 1998 (Table 4).

The strong guestroom demand growth witnessed in Mexico over the past decade is directly attributable to strong gains in international visitation. Since 1993, international visitation to Mexico (which, by some estimates accounts for roughly 40 per cent of the country's total annual guestroom demand) has only once finished with an annual growth rate below 4.3 per cent. Figure 6 pinpoints the correlation between international visitation and demand growth.

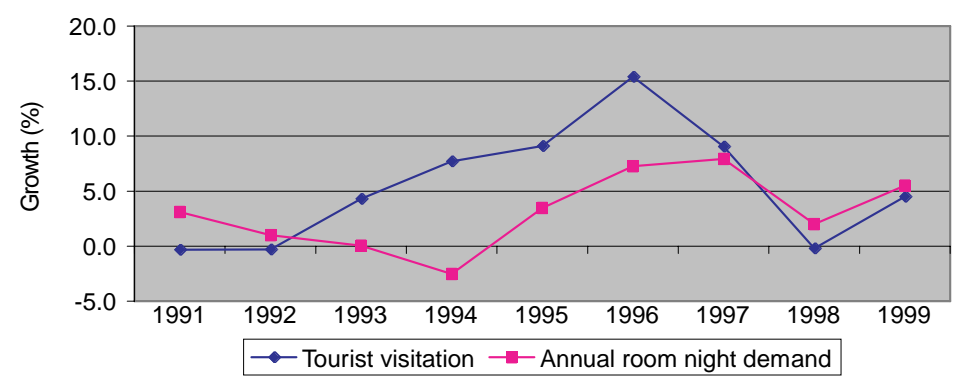

Figure 6: Growth in visitation

\section{THE BOTTOM LINE}

Reasons to remain sceptical still exist - a unique attitude towards doing business and the inefficiency of the country's lodging market and overall economic structure are discouraging to many. However, the inefficiency is now swinging in favour of the foreign investor; a host of existing lodging facilities in Mexico are being sold at or below construction cost, while the Mexican economy is as stable as it has ever been. For any investor who ever dreamed of quickly 
Table 4: Guestroom demand (1990-1999)

\begin{tabular}{|c|c|c|c|c|}
\hline \multirow[b]{2}{*}{ Year } & \multicolumn{2}{|c|}{ Mexico } & \multirow{2}{*}{$\frac{\text { USA }}{\text { Annual }}$} & \multirow[b]{2}{*}{$\begin{array}{c}\% \\
\text { change }\end{array}$} \\
\hline & $\begin{array}{c}\text { Annual } \\
\text { guestroom demand }\end{array}$ & $\begin{array}{c}\% \\
\text { change }\end{array}$ & & \\
\hline 1990 & $65,863,858$ & - & $738,030,000$ & - \\
\hline 1991 & $67,904,856$ & 3.1 & $727,445,000$ & $(1.4)$ \\
\hline 1992 & $68,581,668$ & 1.0 & $742,775,000$ & 2.1 \\
\hline 1993 & $68,610,875$ & 0.0 & $755,915,000$ & 1.8 \\
\hline 1994 & $66,883,993$ & $(2.5)$ & $778,545,000$ & 3.0 \\
\hline 1995 & $69,201,290$ & 3.5 & $792,780,000$ & 1.8 \\
\hline 1996 & $74,223,197$ & 7.3 & $810,300,000$ & 2.2 \\
\hline 1997 & $80,109,082$ & 7.9 & $830,375,000$ & 2.5 \\
\hline 1998 & $81,719,832$ & 2.0 & $856,290,000$ & 3.1 \\
\hline 1999 & $86,227,346$ & 5.5 & $879,285,000$ & 2.7 \\
\hline \multicolumn{2}{|c|}{ Average Annual change (1990-1999) } & 3.0 & & 2.0 \\
\hline
\end{tabular}

Source: Secretaria de Turísmo, Mexico; Smith Travel Research; HVS International

penetrating the Mexican lodging and tourism market, now is the time to capitalise on the wide range of deals that can offer just that possibility. 